\title{
Contemporary architectural interventions in the historical tissue of Cádiz - contextual minimalism in the service of genius loci
}

\author{
Joanna Jadwiga Białkiewicz \\ https://orcid.org/0000-0002-8827-9397 \\ jbialkiewicz@pk.edu.pl \\ Institute of History of Architecture and Monument Preservation, \\ Faculty of Architecture, Cracow University of Technology
}

\begin{abstract}
Discussions devoted to the contemporary approach to the historical heritage usually evoke strong emotions, residing somewhere between the conceptual poles of mimetic reproduction and ruthless anastylosis of forms and materials. Against this background, the four projects implemented in Cádiz, Spain, described in this paper appear to be very successful in their somewhat subdued formal character, the emphasis put on functionalism and space revitalisation, and the application of the concept of transparent architecture not conflicting with the historical one, non-aggressive, and at the same time thoroughly modern.
\end{abstract}

Keywords: Cádiz, Between Cathedrals, Alberto Campo Baeza, Genoves Park, José Luis Bezos Alonso, Mercado Central, Carlos de Riaño Lozano, Teatrum Balbi, Tomás Carranza Macías, Francisco Javier Montero Roncero, Castle of Matrera, Carlos Quevedo Rojas

\section{Introduction}

Cádiz is regarded as the oldest city in Spain and one of Europe's oldest still inhabited towns. Situated in the south of Andalusia on a narrow peninsula separating a branch of the Gulf of Cádiz from the Atlantic Ocean, over centuries of its turbulent history the city was subjected to different influences and impacts, which has found its reflection in the heterogenous stylistic character of the local architecture. The town of Gadir was founded in ca. 1100 BC by Phoenicians, whereupon it came under the rule of Carthage and Rome (since 206 BC). In the $5^{\text {th }}$ century it was destroyed by Visigoths, from the $8^{\text {th }}$ century for over 500 years it was under the Moorish rule, and starting from 1262 it was in the hands of Castile. The majority of ancient and medieval architecture of Cádiz was destroyed in 1596, when the city was plundered by English troops under the command of the Earl of Essex, after a previous defeat of the Spanish fleet by Francis Drake ${ }^{1}$. From the perspective of conservation, the architectural heritage of Cádiz reveals many interesting elements, both due to the presence of relics reaching back to deep Antiquity and taking into account the scarcity of preserved buildings from before the $16^{\text {th }}$ century, which makes it particularly valuable in the context of protection and exposition. Finally, the unique character of the city is also determined by the stylistic diversity of its architecture, from antiquity, through Moorish influences,

1 See: https://www.britannica.com/place/Cadiz-Spain; E. Nash, 'Europe's oldest city' is found, 2007, https://www.independent.co.uk/news/world/ europe/europes-oldest-city-is-found-5328361.html; https://encyklopedia.pwn.pl/haslo/Kadyks;3918943.html; H. Radziszewski, Mityczne początki Kadyksu: wybór źródeł, "Studia i Materiały Archeologiczne" vol. 12, 2005, pp. 163-168; http://www.cadizturismo.com/destinos/ provincias/cadiz/municipios/cadiz/historia; P.E.J. Hammer, Myth-Making: Politics, Propaganda and the Capture of Cadiz in 1596, 1997, https://www.cambridge.org/core/journals/historical-journal/article/mythmaking-politics-propaganda-and-the-capture-of-cadiz-in-596; A. Morgado García, A. Horozco, Historia de Cádiz, Cádiz 2001. 
Gothic and Renaissance, through a rich representation of the Baroque architecture from the $17^{\text {th }}$ and $18^{\text {th }}$ century $^{2}$. In this respect what appears to be particularly interesting are contemporary architectural interventions, implemented in the direct vicinity of historical sites and adapting them to the purposes and functions of a modern city, respecting their historical character. In this regard several very successful as well as controversial projects can be observed in Cádiz, constituting an interesting comparative material. This paper focuses on five sites, different in terms of their functions, as well as the character of the historic structures they refer to. These are: the architecture of Entre Catedrales, Genoves Park, Mercado Central, the adaptation of Theatrum Balbum, and the reconstruction of the Castle of Matrera.

\section{Between cathedrals (entre catedrales)}

In 2009 in the historical city centre modern development, designed 3 years before by Alberto Campo Baeza, came into being, completing and developing the space between the "old" and "new" cathedrals ${ }^{3}$. The so-called Old Cathedral devoted to the Holy Cross (today Iglesia de Santa Cruz) was completed in 1263 and destroyed in 1596. Its reconstruction in a style manifesting the influences of the Renaissance architecture was undertaken in the early $17^{\text {th }}$ century; soon, however, it turned out that this prosperous and quickly developing city needed a bigger cathedral church. Hence in 1722 in the distance of only a bit more than 40 metres to the west from the existing edifice the construction of a new temple was commenced, supervised by Vicente Acero, a designer of the cathedral in Granada. A long construction process, lasting over a hundred years (completed in 1838), resulted in Rococo elements appearing in the initially Baroque "New" Cathedral (Catedral de la Santa Cruz sobre el Mar) and in the overall Neo-Classicist style of the temple. The space between the "old" and "new" cathedral on one side and the seashore on the other is the so-called Campo del Sur, and along the line linking the two temples there is the Episcopal Palace (Casa del Obispo), which today houses an incredibly valuable for the city archaeological exposition with exhibits documenting the turbulent history of Cádiz, from Phoenician anthropomorphic sarcophagi from the $6^{\text {th }}$ century BC, through Roman cisterns, a fountain, and a peristyle with a mural, as well as a cryptoporticus from the time of glory of the empire, to a fragment of a medieval wall ${ }^{4}$. Already at the beginning of this century it was discovered that the archaeological remains under the episcopal palace go beyond the outline of the today's edifice and are located under a considerable part of the surface of Campo del Sur. In 2006 the City Council announced a competition for the development of space between the cathedrals, in which the basic criterion was to secure the archaeological findings in situ, simultaneously allowing for further exploration under the surface of the piazza.

The main functional objective of Baeza's project was, therefore, to expose and protect the archaeological site in Campo del Sur, and a secondary one was to create a public space with an open view of the sea, undisturbed by the perspective of the traffic. On the surface area of a thousand square metres Baeza designed a trapezoid platform, elevated 2.5 metres above the excavation site, parallel to the southern façade of Casa del Obispo. The entrance to the platform is through a ramp, which brings associations with a gangway leading to a ship. The metal frame of the structures and the pillars that support it are painted white, which adds lightness as well as neutrality to the form, making it seem non-aggressive. The space of the excavations under the surface is closed with glass panels, protecting the archaeological site and at the same time making it visible to passers-by from the street level. The surface of the platform constitutes a public space, a vantage point open towards the waterfront. It is surrounded with a simple metal barrier, also painted white, with the exception of the southern edge facing the sea, where instead of the fence the designer proposed a rectangular recess, a gutter, on the edge of which you can sit and enjoy the view. The platform and the ramp are covered with a mosaic of $10-\mathrm{cm}$

2 Possible examples in this respect could be the so-called Admiral's House (Casa del Almirante) in Plaza de San Martin, the church of Nuestra Señora de La Palma, the church of St. Anthony of Padua, Women's Hospital (Hospital de las Mujeres), or the church of St. Philip Neri at Calle Santa Ines, an excellent example of Andalusian Baroque.

3 According to the architect: "The project Between Cathedrals seeks to create an intervention worthy of the most significant location in the history of Cadiz, the oldest city of the West: the empty space facing the sea located between the Old and New Cathedrals". See: Between Cathedrals / Alberto Campo Baeza, https://www.archdaily.com/55969/between-cathedrals-alberto-campo-baeza; N. Schmidt, 'Between Cathedrals' by Estudio Arquitectura Campo Baeza, 2010, https://www.dailytonic.com/between-cathedrals-by-estudio-arquitectura-campobaeza-es/.

4 See: D. Bravo Bordas, Gazebo next to the cathedral, https://www.publicspace.org/works/-/project/f155-gazebo-next-to-the-cathedral. 
cubes of white Macael marble. Eight metal pillars stem to the height of six metres above the plate, creating a canopy-like structure protecting against the rain and the scorching Andalusian sun. In functional terms, there is no doubt that Baeza's work fulfils its task perfectly well, not only protecting the excavation site and exposing it, but also reclaiming the urban significance of the piazza. The structure of the platform, elevated above the traffic, opens up an undisturbed view of the sea and symbolically bonds the space of history with the space of nature. The form is undoubtedly minimalist, extremely economical, unobtrusive, which is fostered by the white colour dominant. At the same time, it is strongly founded in the context of this place, evoking associations with a ship turned towards the sea. The canopy, on the other hand, was intended by the architect to make reference to the tradition of religious processions. An element that is equally important in Baeza's work is the combination of materials - the modern and at the same time neutral steel and glass with white marble, strongly corresponding to the history of Cádiz, as this is the material that the Phoenician sarcophagi found here are made of. For the sake of fuller material integration of the entire project, the southern façade of Casa del Obispo is covered with limestone piedra lumaquela, which with its shade and structure corresponds with piedra ostionera, used as the building material of the walls of both temples. Extreme simplicity, purity, lightness, and brightness of the form designed by Baeza evoke its quasi-religious character, which also symbolically fits in the context of this place . $^{5}$ As the architect said himself, his fundamental objective was to create "beautiful architecture" capable of taking advantage of the potential of the place and of preserving its historical memory ${ }^{6}$.
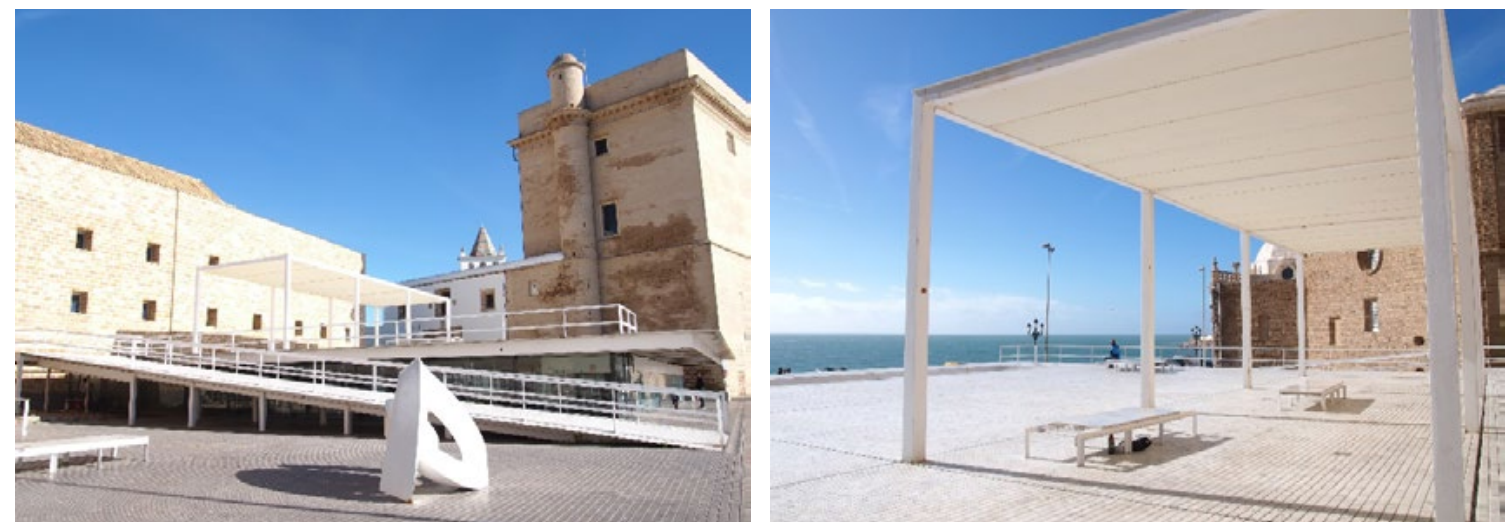

Fig. 1, 2. The platform "Between the Cathedrals", Cádiz, 2018. Photo: Author.
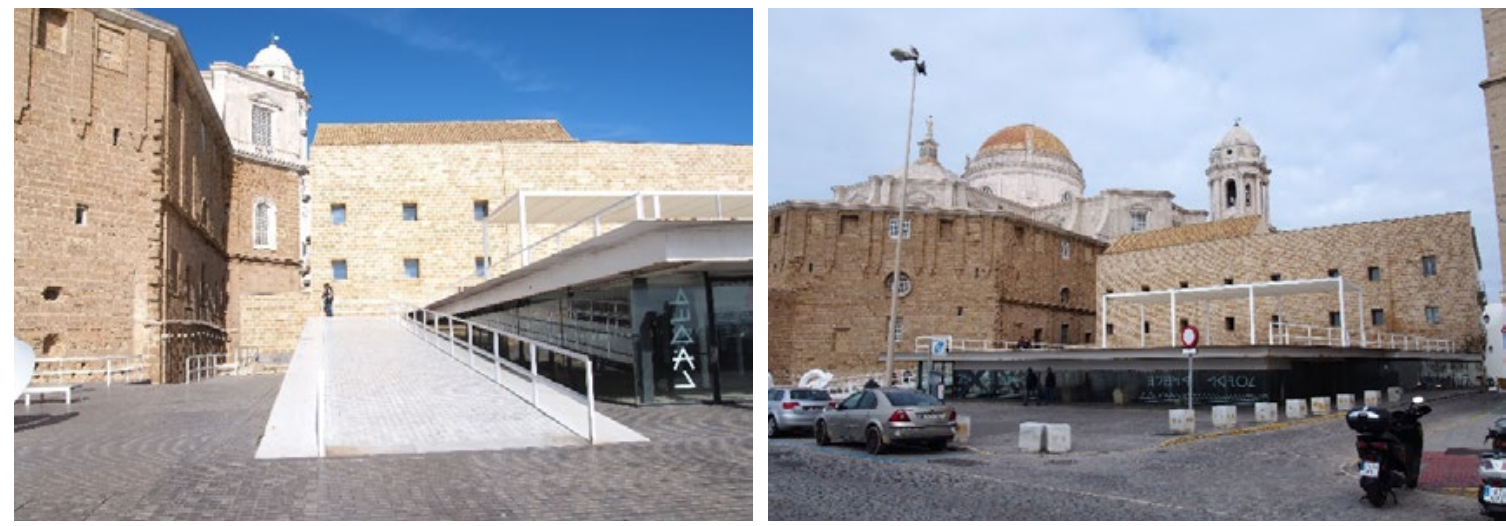

Fig. 3, 4. The platform "Between the Cathedrals", Cádiz, 2018. Photo: Author.

5 See: Transcending Architecture. Contemporary Views on Sacred Space, ed. J. Bermudez, CUA Press 2015.

6 "The entirety is built with light elements, perhaps metal, as if in shipbuilding, all painted white to accentuate its lightness. (...) The construction of the base recollects ships. The awning above, as if a canopy on poles, recollects a religious procession. We wish to make a beautiful piece of architecture, capable of revealing this marvelous place to its best advantage, capable of remaining in the memory of Cádiz". See: N. Schmidt, op. cit. 


\section{View promenade and structures of Genoves Park}

Another interesting modern solution of a public space in Cádiz are structures protecting Genoves Park from the side of the sea, a botanical garden whose history reaches back to the $18^{\text {th }}$ century and which in its current form was arranged in 1892 by a gardener from Valencia, Gerónimo Genovésa y Puiga. The garden owes its special character to the presence of numerous rare species of plants brough by Spanish conquerors from the New World. Genoves Park is situated at the eastern end of the city, on the ocean shore. In order to protect fragile plants and trees against changeable weather conditions and the sea breeze, the garden was furnished with a 130-metre-long stone fence facing the waterfront, erected along St. Barbara esplanade, used predominantly as a car park. In the first years of this century an underground car park was put into use under the esplanade, which allowed to reduce the number of cars occupying the wharf. Despite a single door, most often locked and not used, the wall of the esplanade separated the eastern part of the wharf from the rest of the city and made this cut-off space completely forgotten in terms of urban planning. For the purposes of its revitalisation, in 2011 an international competition was announced upon the initiative of the City Hall and the Society of Architects, won by a design by José Luisa Bezos Alonso ${ }^{7}$, which was implemented in 2013-2015 ${ }^{8}$. The basic function of the new structures of the esplanade - protection of the botanic garden - was to remain a priority, and an additional goal was an urban revival of the part of the wharf adjacent to the park, which was perfectly implemented in the awarded design. Instead of the stone wall, a multi-use building came into being with the floor area of nearly two thousand square metres and the height of two storeys, with a zigzag shape based on the structure of the underground car park, so that entrances to the car park are within its perimeter. At the ground floor level there are 5 portico passages, linking Genoves Park with St. Barbara esplanade. Functionally, the structure houses utility rooms of the park, storages, locker rooms of garden employees, and public toilets. The upper floor houses offices and open spaces to be used for cultural purposes. The first floor façade is finished with panels of transparent polycarbonate, illuminated after dark, which visually dematerialises the entire structure. The roof of the building, accessible via ramps leading from the level of the basement, has become an open promenade with the view of the sea on one side and of the garden on the other. The dynamic form of the structure combined with the sense of its visual lightness obtained thanks to the materials used, as well as its multifaceted functional programme, constitute a radical contrast to the previous solution of a uniform, inaccessible wall. The project by José Bezos Alonso is difficult to classify typologically. One can conclude it is an urban solution combining multiple functions inside the building, as well as resulting from its orientation, shape, and interaction with the adjacent areas. Genoves and St. Barbara esplanade are linked by this solution, providing city residents and tourists with an opportunity to move between the garden and the waterfront freely, and creating a beautiful panorama view of the bay. The architect himself declares that what inspired him was a mural by Banksy, who redid the inscription "PARKING" on the wall by painting over the "ing" ending and adding a little girl on a swing suspended on the letter " $\mathrm{A}^{\prime \prime}$. Therefore, the idea was to extend the space of the park by combining it with something it used to be separated from, that is the waterfront, and at the same time to revive the waterfront by liquidating the car park and creating a recreational space instead. One could say that what we deal here with is architecture which undertakes a dialogue with the conditions of the place, as well as with the needs of all the people who occupy it, the ones who look for respite, tourists, and park employees alike. Certainly we can talk about revitalisation understood in the best possible way. The wall, a uniform, separating, closing structure, practically as well as symbolically, marked with connotations of separation and cutting off, has been replaced with a dynamic structure, modern in form, but at the same time not aggressive visually despite its dimensions, and interactive with the urban space, satisfying multiple urban needs ${ }^{10}$. The concept of the specific dematerialisation of the structure by using modern materials, such as glass, polycarbonate, and

7 Genoves Park's Lookout and Protection Building / José Luis Bezos Alonso, http://www.archdaily.com; M. Corradi, Genoves Park, http://www. floornature.com/panoramic-viewpoint-and-defence-structure-in-park-genoves-cadiz; http://joseluisbezos.com/wordpress/urbanizaciondel-nuevo-paseo-de-santa-barbara/

8 See: Protection Building of the Genovés Park Cádiz (Spain), 2015, http://www.publicspace.org.

9 "El proyecto, como si se inspirara en el conocido graffiti de Baksy, la convierte ahora en una extension del parque y un espacio libre con franjas de zonas ajardinadas, deportivas y para juego de niños. Los niños juegan ahora donde antes sólo había coches." Zob. http:// joseluisbezos.com/wordpress/urbanizacion-del-nuevo-paseo-de-santa-barbara/

10 "(...) the protective structure is not seen as a limit or barrier any more but more as a point of contact due to the connection created by the transparent boundary between the sea and the nature in the botanical park with its exotic American plants." See: M. Corradi, op. cit. 
steel, link the character of this building with the previously discussed project Entre Catedrales. Although they have been conceived by different authors, both solutions are connected by the concept of a transparent, modern architectural form, which does not impose itself, which is not imitative, and the same time which is not in conflict with the existing historical architecture and is functional in terms of urban planning. Both projects share an emphasis on the making use of the existing view perspectives and creating new ones, taking full advantage of the picturesque location of the city and the fact it faces the bay.
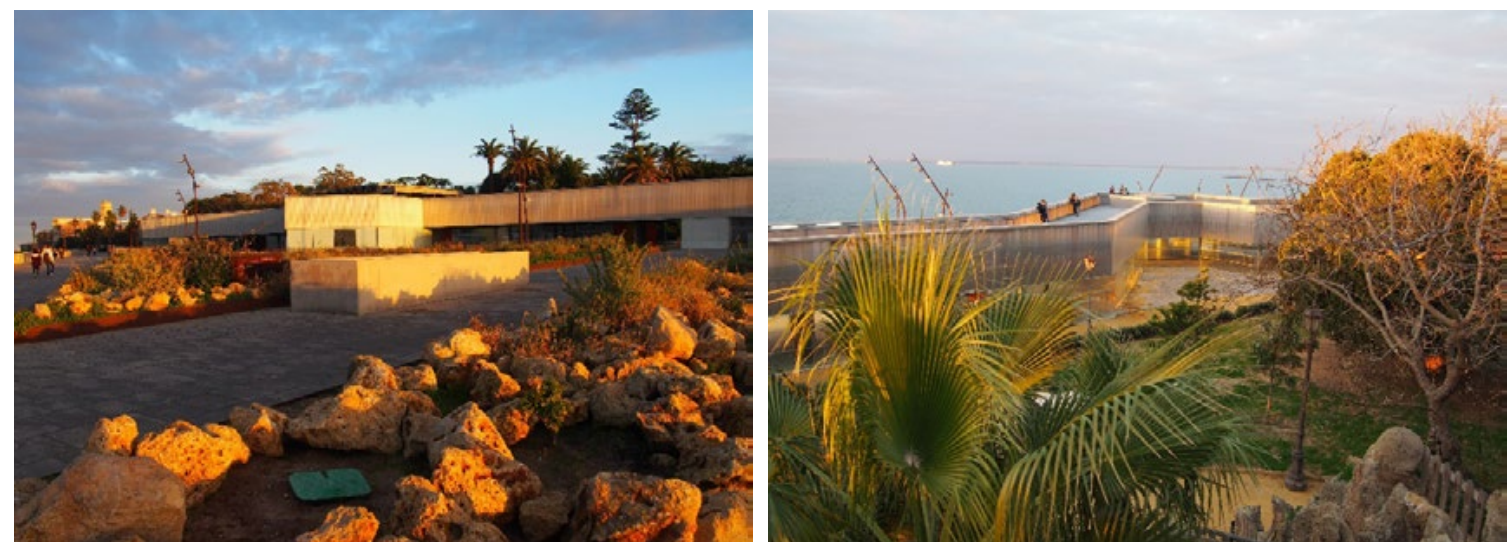

Fig. 5, 6. View promenade and structures of Genoves Park, Cádiz, 2018. Photo: Author.
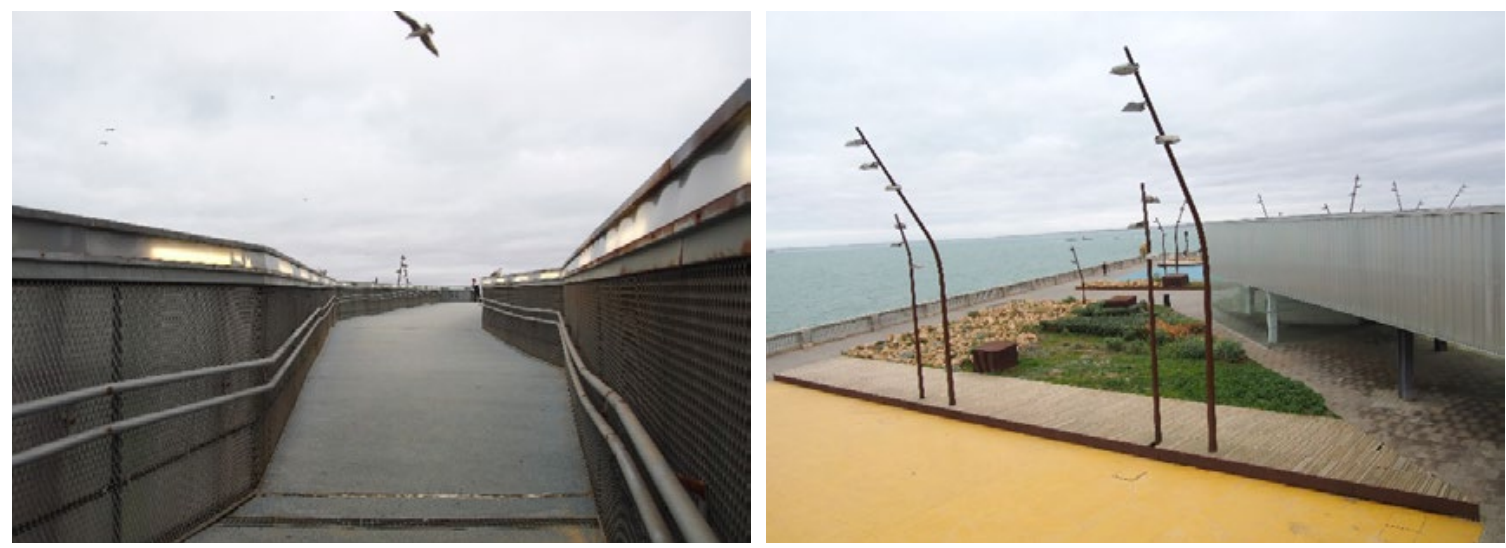

Fig. 7, 8. View promenade and structures of Genoves Park, Cádiz, 2018. Photo: Author.

\section{Mercado Central de Abastos}

Mercado Central in Cádiz is one of the first historical buildings of the type in Spain, erected at the same time as the buildings of Plaza de la Encarnación in Seville and the market square in Puerto Real ${ }^{11}$, earlier than the squares in Madrid and Barcelona, which came into being in the mid-19 ${ }^{\text {th }}$ century. In functional terms it was an interim form between a completely open market square and what later on could be called a market hall. The first building of Mercado Central de Abastos in Cádiz, built in the Neo-Classicist style, was completed in 1838 according to a design by Torcuato Benjumeda, continued after his death by another architect, Juan Daura. It was erected at Plaza de la Libertad, in the place of the former convent Los Desclazos. Four wings of 2-floor buildings surrounded the rectangular market square in the middle. The façades of the internal peristyle were designed as 
Neo-Doric porticos supported by impressive 4-metre-tall columns, bringing associations with ancient temples in Paestum and Agrigento. In the middle of each wing there was an arched passage, ornamented with decorative tympana. In its first Neo-Classicist shape Mercado Central survived one century, until 1929, when it was rebuilt according to a concept of an architect Juan Talaver y Heredia. A roofed pavilion in the centre of the square was built at the time. The main problem of this building was the lack of appropriate ventilation, necessary in a place frequented by many people trading in food products, as well as the lack of access of natural daylight. The need to revitalise the square in a form addressing contemporary requirements was pursued in the first decade of this century. The decisive reconstruction took place in 2006-2009, according to the concept developed by Carlos de Riaño Lozano, selected in a closed competition organised by the department of architecture and urban planning of the Ministry of Public Works, to which only ten architects had been invited. The goal of the new project was the demolition of the inner part and simultaneous exposition of the old $19^{\text {th }}$-century buildings, as well as creation of space which - satisfying all functional requirements for such structures - would at the same time return, if only partially, to the original idea of an open piazza. The Neo-Classicist building was subjected to a careful renovation, exposing the original brick details of its façade, and the new structures in the middle were built in a minimalist style, which provides the contemporary architecture with transparency, like it is the case in the solutions of Entre Catedrales and Genoves park discussed above, thanks to which it can neighbour on historical buildings without conflicting them, but instead emphasising them and enhancing the functionality of the public utility space.

Mercado Central occupies the area of nearly seven thousand square metres on Libertad square, between the streets Libertad and Alcalá Galiano. It has a shape of a rectangle with the longer side of 106 metres and the shorter one of 56 metres. An idea that guided the architect after the demolition of the central part was - besides setting the Neo-Classicist buildings free - to re-integrate visually the market space with the urban tissue that surrounds it. Thanks to the new building erected in the middle of the square, but with a proper margin and a "spatial breath", creating a new view and a perspective of the $19^{\text {th }}$-century colonnades, the effect - intended already by Benjumeda - of intermingling of the market square with the street was achieved, where the street enters the perimeter of the square, and the square reaches out to the street. What we deal here with is a dialogue of the urban space and two generations of architecture, with the contemporary one serving functional purposes, as well as fostering the protection and exposition of the historical tissue. By comparing plans and sections of the structures from 1929 and the contemporary ones, one can easily notice that the structures from the early $20^{\text {th }}$ century were not only closely connected with the $19^{\text {th }}$-century development, but they competed with it visually, altering the perspective of the initial buildings and disturbing its proportions. The modern building is clearly moved away from Benjumeda's colonnades, and thanks to the applied forms and materials it is not their competition, but a stylish background. It is a deliberate shift of emphasis and giving the contemporary minimalist architecture the role characteristic for all of the sites in Cádiz discussed above. In the plan of the new Mercado Central we can see 3 rows of double stalls arranged along the longer sides of the rectangular piazza. In total there are 169 such stalls, 57 of which sell fruit and vegetables, 54 - seafood, 44 - meat, 7 - general food products, in 4 stalls you can buy breadstuff; furthermore, one stall offers olives, one - paper bags, and one - fishing products. Along the shorter sides the architect designed covered staircases leading to glazed rooms above the level of the stalls, housing offices, a coffee shop, and archives. In the two extreme rows the stalls are separated by 3.30-metre-tall simple white concrete screens, supporting a protruding roof that provides shelter for customers from the outside. From its level there stem $30 \times 60 \mathrm{~cm}$ rectangular pillars, which - combined on both sides with 130-metre-long girders - support the roof above the central part of the market space. Between the pillars the architect proposed blinds made of screen-printed glass strips for the effect of a shadow, positioned at the angle of 45 degree, fixed on a stainless steel frame. The application of glass provides the architecture of the new Mercado Central with the value of transparency, referred to herein many times, thanks to which the contemporary architecture becomes completely non-aggressive visually and may serve the purposes of exposition of historical buildings. At the same time, this openwork structure allows for proper ventilation of the hall, so much desired. White concrete and glass blend in well with $19^{\text {th }}$-century materials and constitute a neutral background for them. This modern building satisfies all functional requirements and can be recognised as a very successful intervention into a historical site. 

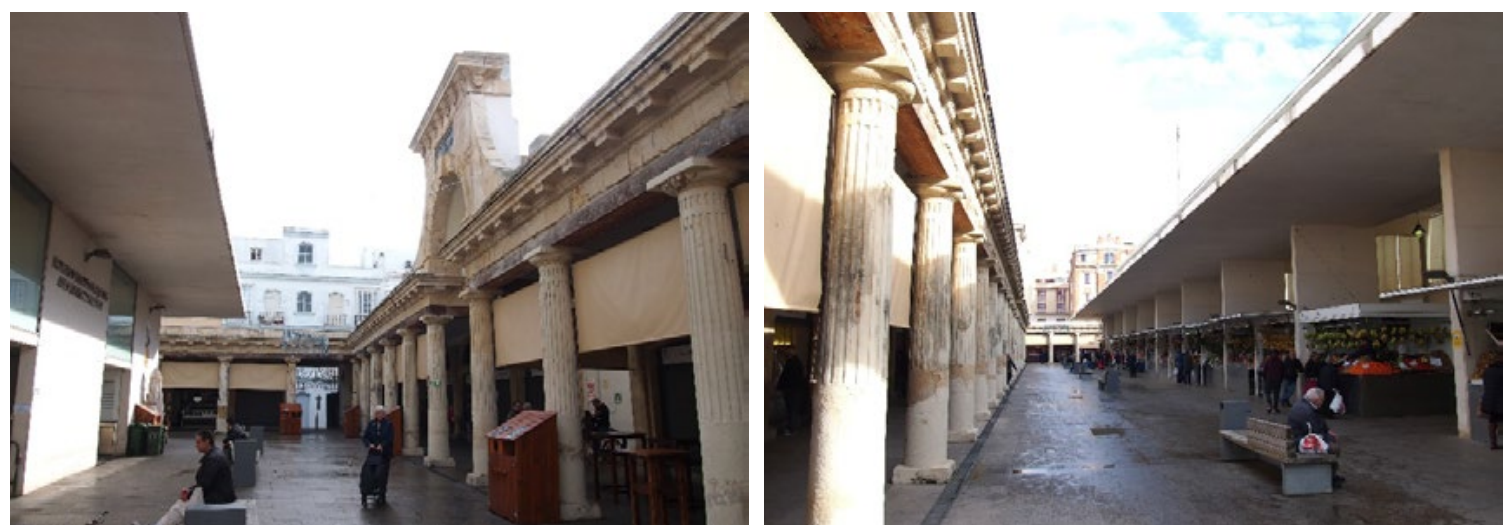

Fig. 9, 10. Mercado Central de Abastos, Cádiz, 2018. Photo: Author.

\section{Theatrum Balbi}

Teatrum Balbi in Cádiz is one of the two oldest Roman theatres in the world, next to the theatre in Pompeii, and at the same time it is Spain's second largest Roman theatre, after Córdoba ${ }^{12}$. Erected in the second half of the $1^{\text {st }}$ century ${ }^{13}$ by politician Lucius Cornelius Balbus Minor, this structure with the diameter of nearly 120 metres could accommodate as many as ten thousand viewers. It was made of stone combined with mortar (opus caementicum), with decorative elements made from marble and bronze ${ }^{14}$. The theatre was in use until the $3^{\text {rd }}$ century $A D$, it was destroyed during the invasions of Vandals and Visigoths, for centuries its remains were forgotten under subsequent developments. Probably already in the $8^{\text {th }}$ century a Muslim fortress was built on the ruins of the theatre, thoroughly reconstructed in the $13^{\text {th }}$ century after the recovery of Cádiz by King Alfonso $X$. The history of the castle of Alfonso $X$ of Castile was equally turbulent. At the end of the $16^{\text {th }}$ century it was rebuilt after the city had been plundered by the Earl of Essex; in the $18^{\text {th }}$ century it housed a naval academy and an astronomical observatory. Eventually, it was destroyed completely in the $19^{\text {th }}$ century, probably at the same time as the city walls and gates. In the early $20^{\text {th }}$ century Vigorito warehouses were built within the perimeter of the former fortress, which burnt down in 1979. One year later, in 1980, the ruins of the Roman theatre were discovered. The main problem that accompanied the uncovering of the remains of the ancient structure was the dense development of the today's district of El Pópulo and the vicinity of valuable historical buildings, such as the Old Cathedral, the remains of the city walls, or the palace of Posada del Mesón 15. Archaeological works were carried out for over thirty years, with the application of the most advanced methods. Underneath the development of El Pópulo special vaults were built, protecting the excavations like umbrellas, and at the same time supporting the buildings above. Eventually, the ruins of the theatre were opened to the public in 2015. The uncovered left side of the auditorium (ca. a half of the initial volume), consisted of cavea ima, cavea media, and proedria, as well as vomitoria, orchestra, and a perfectly preserved 180-metre-long ring-like vaulted

12 See: P. Pachon, E. Rodriguez-Mayorga, J. F. Jimenez, V. Compan, A. Saez, E. Yanes, Application of the operational modal analysis method for the control of the intervention in the Roman Theatre (Cádiz, Spain), [in:] Structures and Architecture: Concepts, Applications and Challenges, ed. P. J. Cruz, London 2013, pp. 904-911; El Theatrum Balbi de Gades: Actas del Seminario «El Teatro Romano de Gades. Una Mirada al futuro» (Cádiz, 18-19 noviembre de 2009), ed. D. Bernal Casasola, A. Arévalo González; https://cometocadiz.com/theatrum-balbi-in-gadesroman-cadiz; Teatro romano de Cádiz, http://www.juntadeandalucia.es/cultura/enclaves/enclave-arqueologico-teatro-romano-de-cadiz; R. Corzo Sánchez, El teatro romano de Cádiz, "Teatros romanos de Hispania" 1992, pp. 133-140; J. M. Esteban González, A. Muñoz Vicente, F. J. Blanco Jiménez, Breve historia y criterios de intervención en el teatro romano de Cádiz, "Teatros romanos de Hispania" 1992, pp. 141 -156.

13 According to such authors as Cicero and Strabo, the construction of the theatre dates back to the years $46-43$ BC; the uncovered remains indicate it was rebuilt in the times of Emperor Augustus, between 29 BC and 14 AD. See: A. Alvarez-Corbacho, P. Bustamante, T. Zamarreño, M. Gallindo, Acoustic Reconstruction of the Roman Theatre of Cadiz, http://www.sea-acustica.es

14 See: V. Perondi, El Teatro Romano que se resistió a morir, 22.07.2017, https://www.lavozdelsur.es/el-teatro-romano-que-se-resistio-a-morir/ El Teatro Romano de Cádiz como referente económico y cultural, https://turismoandaluz.eldesmarque.com/cultura/243-el-teatro-romanode-cadiz-como-referente-economico-y-cultural

15 See: P. Pachon, E. Rodriguez-Mayorga, J. F. Jimenez, V. Compan, A. Saez, E. Yanes, op. cit., pp. 905-907; V. Perondi, op. cit. 
gallery, leading to the auditorium ${ }^{16}$. The Interpretation Centre (Centro de Recepción e Interpretación del Teatro Romano de Cádiz) organised in the $17^{\text {th }}$-century building of Posada del Mesón under the supervision of architects Tomás Carranza Macías and Francisco Javier Montero Roncero, constitutes a specific complement and extension of the archaeological exposition ${ }^{17}$. The arrangement centre, modern in form and making use of the latest museum solutions, blends with the ancient ruins into an excellently harmonised whole, at the same time taking advantage of the modern buildings erected above the remains of the theatre. This way a unique contextual historical continuum is created, demonstrating the rich history of the city, from its ancient roots, through its turbulent history, to the modern times, with technological achievements allowing to exhibit ancient ruins without any harm to the existing development. What initially seemed to be an obstacle - the location of the excavations under valuable modern buildings, in the very heart of El Pópulo - was used as an advantage, thanks to which a very original exposition came into being, compiling several generations of architecture into a coherent whole. It is yet another current solution in Cádiz where the contemporary minimalist architecture constitutes a perfect neutral background for the historical tissue, serving both functional goals at the same time. The leitmotif that bonds this architectural whole is an arch, deriving from the vault of the theatre gallery and reiterated in the vaults cutting into the buildings above the ruins covering the excavations, as well as referred to many times in the arrangement of the exposition itself.

In Centro de Interpretación, via advanced interactive audio-visual solutions, viewers take a trip in time, from the views of El Pópulo in Room A, through modern views and plans of Cádiz in Room B, Room C devoted to Teatrum Balbi itself and its architecture, to Room $D$, which undertakes the topic of the meaning of theatre in the Roman society ${ }^{18}$. Visitors can see a model of the original building, and four round glazed openings in the floor allow to admire fragments of uncovered sections of the excavations. In the vestibule - Room A - you can see a fragment of scaenae frons, in Room B - proedria and a part of the section cavea, and in Room D - orchestra. Room C presents also the found fragments of decorative stonework, for instance a stone which is a part of one of the seats, with an inscription "Latro Balbo" (Balbo the thief), which was most probably the work of one of dissatisfied builders of the theatre ${ }^{19}$. The exhibition is arranged in a minimalist, modern form, dominated by wood and whites, enhanced with skilfully designed lighting arranged in slots in the ceiling and LED backlights illuminating the exposition itself, e.g. large-format photographs. The Interpretation Centre demonstrates the ancient remains not as something separate, but in the context - the social one, the context of architecture history, and most of all in the context of the history of the city to the present day.
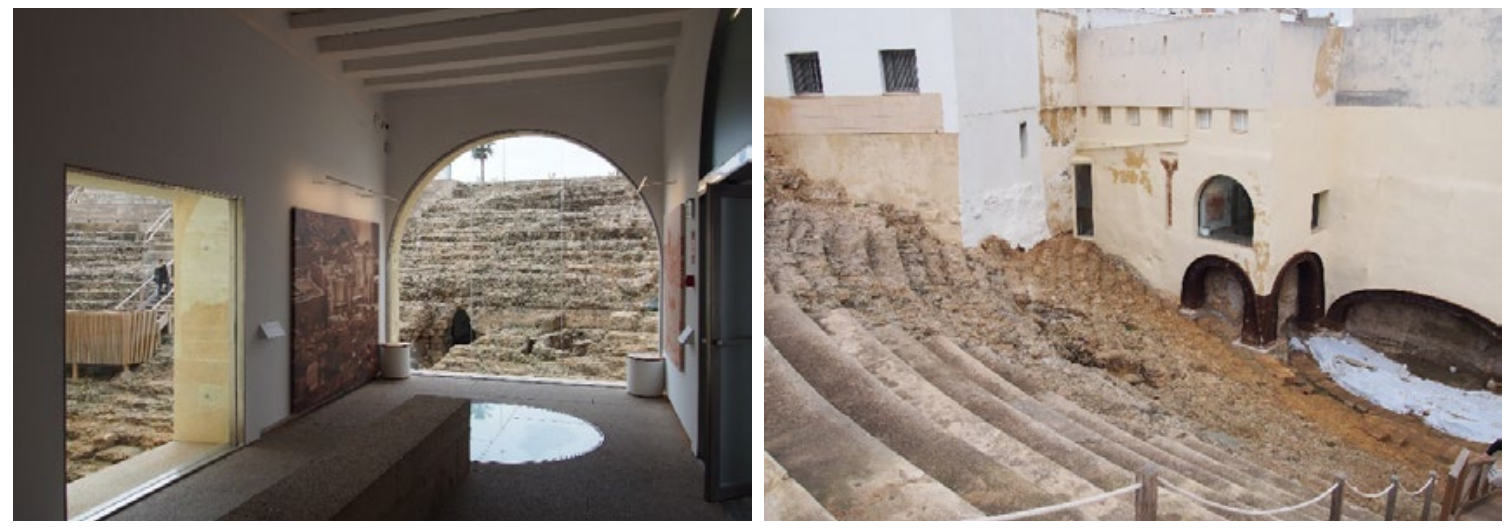

Fig. 11, 12. Teatrum Balbi, Cádiz, 2018. Photo: Author.

16 See: A. Alvarez-Corbacho, P. Bustamante, T. Zamarreño, M. Gallindo, op. cit.

17 See: D. Bernal Casasola, A. Arévalo González, M. Bustamante Álvarez, V. Sánchez Loaiza, De Theatro Balbi Restituendo. Un plan de Investigación para el principal testimonio de la romanidad de Gades (2009-2012), [in:] El Theatrum Balbi de Gades: Actas del Seminario «El Teatro Romano de Gades. Una Mirada al futuro» (Cádiz, 18-19 noviembre de 2009), pp. 257-306; A. Arévalo González, D. Bernal Casasola, F. J. Montero Roncero, T. Carranza Macías, Del Pópulo al Teatro de Balbo. Un Centro de Interpretación para el Doce, [in:] El Theatrum Balbi de Gades: Actas del Seminario «El Teatro Romano de Gades. Una Mirada al futuro» (Cádiz, 18-19 noviembre de 2009), pp. 123-139.

18 A. Arévalo González, D. Bernal Casasola, F. J. Montero Roncero, T. Carranza Macías, Del Pópulo al Teatro de Balbo. Un Centro de Interpretación para el Doce..., pp. 134-139.

19 See: https://aprende.liceus.com/theatrum-balbi-teatro-romano-cadiz/ 


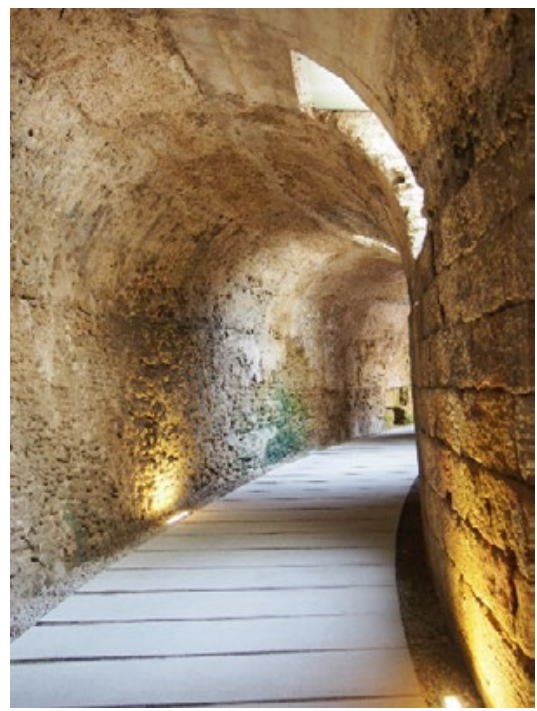

Fig. 13. Vaults of the gallery of Teatrum Balbi, Cádiz, 2018. Photo: Author.

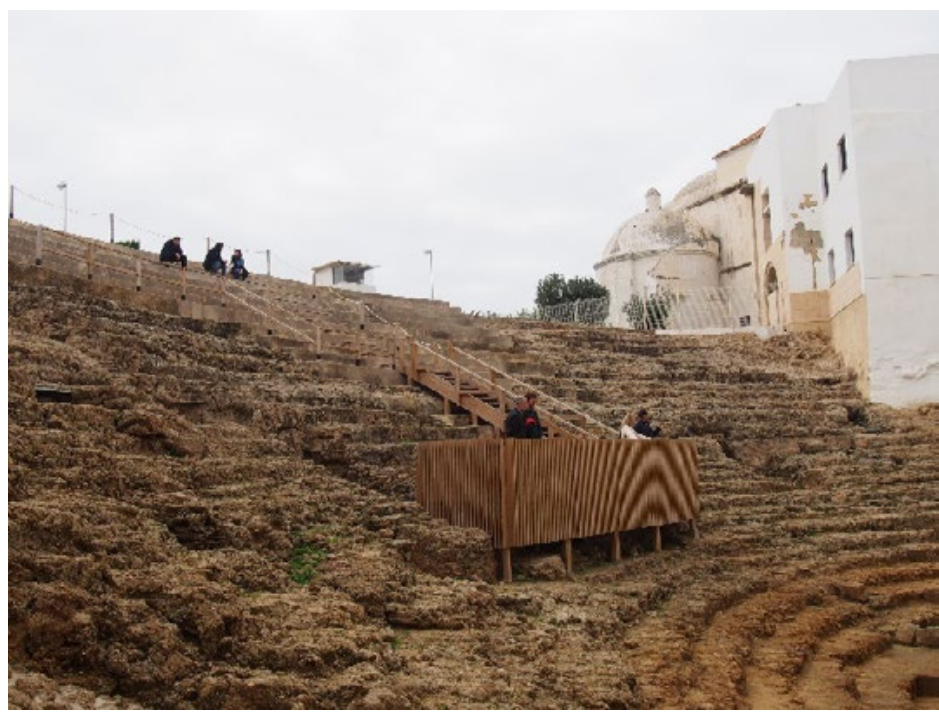

Fig. 14. Teatrum Balbi, Cádiz, 2018. Photo: Author.

\section{Castle of Matrera}

In the context of the four projects discussed above, in which the contemporary interventions should be clearly recognised as very successful, it is worth mentioning a strongly controversial project, evoking extreme emotions, which is the restoration of the tower of the Castle of Matrera. The Castle of Matrera (Castillo de Matrera) is located in Villamartín near Cádiz and it was erected in the $9^{\text {th }}$ century by Omar ibn Hafsún, conquered by Alphonso $\mathrm{X}$ in 1256 , rebuilt and donated to the knightly order Calatrava. In the early $14^{\text {th }}$ century it returned to the hands of Muslims and was eventually taken over by Alfonso XI in $1341^{20}$. Only parts of the fortress survived to the modern times, and in 2013 they were partly damaged by torrential rains that affected this region. Three floors of the tower along with the vaults, the entire northern wall, and a part of the western wall collapsed then. This is when the city authorities decided to renovate the partially preserved tower, and this task was entrusted to architects from the Carquero Arquitectura studio under the supervision of Carlos Quevedo Rojas. The controversial project was completed in $2016^{21}$. The preserved fragments of the Moorish walls were included in the austere rectangular form of the added white concrete tower. Fragments of the limestone from the collapsed parts of the fortress were used in the construction of the buttresses supporting the degraded walls from the inside ${ }^{22}$. The irregularity and texture of the ruins constitutes an exceptionally interesting contrast to the extreme formal frugality of the contemporary addition. According to the architect himself, the project had three fundamental goals: structural consolidation of the preserved parts of the building, clear separation of the contemporary intervention consistent with the Andalusian law on reconstructions of historical architecture, $^{23}$ and quoting the original size, texture, and tone of the tower ${ }^{24}$. This project, in terms of its programme based on the principles of anastylosis, aroused widespread controversy in Spain itself, as well as beyond its borders, becoming a contribution to a heated discussion on the contemporary approach to historical heritage. 
The design by Carlos Quevedo was hailed the most extreme example of contemporary façadectomy ${ }^{25}$; the architect was accused of reducing the priceless fragments of Moorish architecture to a thin historical 'skin' embracing the massive block of smooth white concrete ${ }^{26}$. Conservative institutions involved in the protection of historical heritage, such as Hispania Nostra, did not spare harsh words of criticism to this bold project, and a wave of polemic texts went through the majority of European opinion-making periodicals ${ }^{27}$. Irrespectively of the stylistic evaluation of the reconstruction itself, it is worth pointing out that the previously insignificant ruined castle has become a popular tourist destination due to these events and gained international fame.

The project by the Spanish architect is based on the concept of reconstructing the dimension and form of the castle tower, making use, however, of a raw material, deprived of any details and decorations. In this understanding the smooth bright concrete in the ruins of the Castle of Matreta becomes as brutalist in its ostentatiously contemporary character as it is extremely neutral, like a modern in situ model, a shadow of the original building emerging from behind the preserved fragments of the wall. The spirit of a Moorish fortress has been quoted here in its original grandeur, simultaneously emphasising how little of it is left. According to the architect himself, the essence of the project was not to look into the future, but "to reflect on the past" ${ }^{\text {"2 }}$. Anastylosis is perceived here as highlighting the authenticity of the preserved fragments, whereas their mimetic reconstruction would be - according to the architects from the Carquero studio - only a fake ${ }^{29}$. The objective here is not to obliterate the effects of the passage of time and of the turbulent history, but to emphasise them ${ }^{30}$. At the same time, the smooth surface and the sharp geometrical silhouette of the added part constitute a formal opposition and a background for the irregular structure of the ruins, like a white wall in a museum, against which the preserved remains of the fortress have been presented ${ }^{31}$. The question whether what we deal here with is a violation of the historical structure of the walls, or perhaps a symbolic marriage of the heritage of the past with modernity, seems to remain a question of our own individual reception. It is worth pointing out that apart from critical opinions mentioning "a massacre committed on the national heritage", the restoration of the Castle of Matrera has also received positive reviews, predominantly among architects. It was honoured with the Architizer 2016 A+ award in the category "Architecture and Protection" 32 . Among all controversies, the fact that this is an extremely interesting and noteworthy example of combining historical and modern architecture remains undoubted.

25 See e.g.: A. Weiss, Facadectomy is Preservationists' Biggest Mistake, 03.02.2004, https://www.planetizen.com/; O. Wainwright, Some front: the bad developments making a joke of historical buildings, 25.08.2014, https://www.theguardian.com/artanddesign/architecture-design-blog/

26 See: O. Wainwright, Spain's concrete castle: a case of accidental genius?, 10.03.2016, https://www.theguardian.com/artanddesign/architecturedesign-blog/

27 See: S. Jones, 'What the hell have they done?' Spanish castle restoration mocked, 09.03.2016, https://www.theguardian.com/world/2016/ mar/09/matrera-castle-cadiz-spain-restoration-mocked; 'Botched' Cádiz castle restoration goes global, 16.03.2016, https://www.thinkspain. com/news-spain/27242/botched-cadiz-castle-restoration-goes-global; Controversy erupts over castle restoration in Cádiz, 11.03.2016, https://elpais.com/elpais/2016/03/11/inenglish/1457696211_872057.html; R. Sobot, Is this the world's worst restoration project? Historians furious after Ninth Century Spanish castle is 'repaired' by local builders, 09.03.2016, https://www.dailymail.co.uk/news/article-3484505/ Historians-furious-Spanish-castle-repaired-builders.html

28 "The essence of this project is not intended to be an image of the future (...) Rather, it is a reflection of its own past, its own origin", see: Project of the Week: Matrera Castle, Cadiz, Spain, Carquero Arquitectura..

29 "The proposal aims to avoid the aesthetic mimicry that involves falsification or loss of value of authenticity and, in parallel with the practice in intervention of movable heritage, its historical value is enhanced", see: Carquero Arquitectura restores ancient Matrera Castle with contemporary elements, https://www.dezeen.com/2016/10/03/carquero-arquitectura-matrera-castle-contemporary-restoration-cadizspain-architizer-awards/

30 "(...) this project aims to look at a unifying potential restoration, without undertaking the task of building a false historical monument or cancelling every trace of the passage of time. It tries to approach the work in recognition of the munumentum or memory in its physical consistency and its dual polarity, aesthetic and historical, in order to transmit those two aspects to the future", see: Matrera Castle Intervention Heritage by Carlos Quevedo Rojas, https://competition.adesignaward.com/

31 "The modern additions offer a contrast, yes, but also do not take away from what was a decaying ruin in any real, meaningful way", see: Project of the Week: Matrera Castle, Cadiz, Spain, Carquero Arquitectura...

32 See: Project of the Week: Matrera Castle, Cadiz, Spain, Carquero Arquitectura...; Carquero Arquitectura restores ancient Matrera Castle with contemporary elements...; K. Megson, Spanish architects win international prize for controversial restoration of medieval castle, 14.04.2016, http://www.cladglobal.com/CLADnews/architecture-design/Architezter-A-awards-architecture-design-competition-restoration-MatreraCastle-Spain-Carquero-Arquitectura/323328 


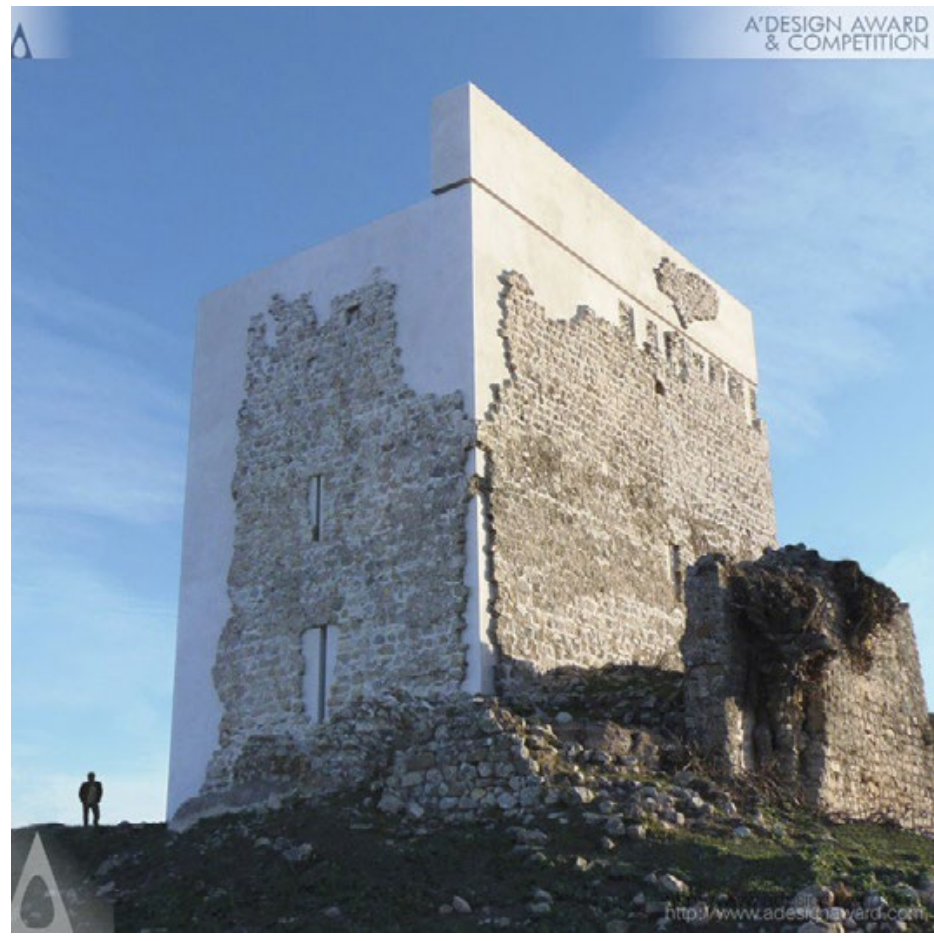

Fig. 15. Photo 15. Consolidation of the tower of the Castle of Matrera, Villamartin, Spain, source: https://competition.adesignaward. com/design.php?|D=48588

\section{Summary}

The common denominator for all of the projects implemented in the urban tissue of Cádiz described above: Entre Catedrales, Genoves park, Mercado Central, and Teatrum Balbi, is the concept of combining historical and modern architecture. The latest architecture uses here most of all the formal language of minimalism: geometric forms and frugality of colours and textures. It is easy to notice that the authors of these designs did not aim to reconstruct or complement the historical structure in an imitative way, but to achieve two fundamental goals: its exposition and functional extension, so that it could find a new place in the urban organism and serve the widest possible group of recipients as extensively as possible. The concept and character of these four projects are inseparably linked with the contemporary city and its needs. The application of modern materials and functional solutions in combination with the formal frugality of minimalism allows to give historical architecture a second life and to include it in the functional programme of the city, highlighting its values at the same time. In the Cádiz-based projects described herein the architects focused on the concept of combining not only history with modernity, but also combining epochs and historical layering, as well as different zones and areas, culture and nature, with the simultaneous creation of a useful space in urban terms on the plane of combination. What we deal here with is a contextual approach to architecture, through the exposition of traces of history and the simultaneous creation of a completely new quality. Each of the described projects experienced a certain redefinition of the existing development, and the latest architecture acts as a bond and clamp connecting different epochs and spaces, at the same time becoming an area of exposition and social utility. Besides minimalism, transparency is the dominating formal concept - modernity is not in conflict with historic architecture, but it creates a transparent background for it - hence the observed frequent use of glass and transparent plastics, the use of light, and the dominating whites. The projects described herein differt from each other not only in terms of scale and functional programme, but also the character of their historical structures: from ruins of an ancient theatre, through modern religious, residential, and commercial buildings, to a colonial botanic garden. In all this diversity, they are connected by the architectural concepts they share: functionality, transparency, contextualism, and symbolic foundation on the idea of a connection plane. Against this background the Castle of Matrera, whose concrete additions evoked strong controversy even beyond the 
borders of Spain, is an exceptionally interesting case. And yet, the design by Carlos Quevedo also satisfies the functional requirement: it protects the ruins facing the risk of collapse. The question whether a smooth geometrical plane constitutes a neutral background for medieval fragments, or rather an aggressive intervention, remains disputable. The location of this project in landscape is probably not without significance. While in an urban landscape sharp edges and geometrical forms are something commonly found, in the case of a castle located on a hill they actually give the impression of a structure completely foreign in the surrounding nature.

\section{Bibliography}

[1] Alvarez-Corbacho A., Bustamante P., Zamarreño T., Gallindo M., Acoustic Reconstruction of the Roman Theatre of Cadiz, http://www.sea-acustica.es [accessed: 10.06.2019].

[2] Arévalo González A., Bernal Casasola D., Montero Roncero F. J., Carranza Macías T., Del Pópulo al Teatro de Balbo. Un Centro de Interpretación para el Doce, [in:] El Theatrum Balbi de Gades: Actas del Seminario «El Teatro Romano de Gades. Una Mirada al futuro» (Cádiz, 18-19 noviembre de 2009), pp. 123-139.

[3] Barou L., Oikonomopoulou F., Bristogianni T., Veer F., Nijsse R., Structural glass: A new remedial tool for the consolidation of historic structures, https://www.researchgate.net/publication/330423091_Structural_glass_A_new_remedial_tool_for_ the_consolidation_of_historic_structures/ [accessed: 27.06.2019].

[4] Bernal Casasola D., Arévalo González A., Bustamante Álvarez M., Sánchez Loaiza V., De Theatro Balbi Restituendo. Un plan de Investigación para el principal testimonio de la romanidad de Gades (2009-2012), [in:] El Theatrum Balbi de Gades: Actas del Seminario «El Teatro Romano de Gades. Una Mirada al futuro» (Cádiz, 18-19 noviembre de 2009), pp. 257-306.

[5] Between Cathedrals / Alberto Campo Baeza, https://www.archdaily.com/55969/between-cathedrals-alberto-campo-baeza [accessed: 25.05.2019].

[6] 'Botched' Cádiz castle restoration goes global, 16.03.2016, https://www.thinkspain.com/news-spain/27242/botched-cadiz-castle-restoration-goes-global [accessed: 28.06.2019].

[7] Bravo Bordas D., Gazebo next to the cathedral, https://www.publicspace.org/works/-/project/f155-gazebo-next-to-the-cathedral [accessed: 26.05.2019].

[8] Cádiz Castle Restoration: Interesting Interpretation or Harmful to Heritage, http://www. archdaily.com/ [accessed: 27.06.2019].

[9] Carquero Arquitectura restores ancient Matrera Castle with contemporary elements, https://www.dezeen.com/2016/10/03/ carquero-arquitectura-matrera-castle-contemporary-restoration-cadiz-spain-architizer-awards/ [accessed: 25.06.2019].

[10] Central Market, http://turismo.cadiz.es [accessed: 20.05.2019].

[11] Controversy erupts over castle restoration in Cádiz, 11.03.2016, https://elpais.com/elpais/2016/03/11/inenglish/1457696211_872057.html [accessed: 30.06.2019].

[12] Corradi M., Genoves Park, http://www.floornature.com/panoramic-viewpoint-and-defence-structure-in-park-genoves-cadiz-10906/ [accessed: 1.06.2019].

[13] Corzo Sánchez R., El teatro romano de Cádiz, "Teatros romanos de Hispania" 1992, pp. 133-140.

[14] El Teatro Romano de Cádiz como referente económico y cultural, https://turismoandaluz.eldesmarque.com/cultura/243-el-teatro-romano-de-cadiz-como-referente-economico-y-cultural [accessed: 18.06.2019].

[15] El Theatrum Balbi de Gades: Actas del Seminario «El Teatro Romano de Gades. Una Mirada al futuro» (Cádiz, 18-19 noviembre de 2009), ed. D. Bernal Casasola, A. Arévalo González.

[16] ¿Es el Castillo de Matrera una nueva chapuza en restauración?, https://www.elmundo.es/andalucia/2016/03/11/ [accessed: 29.06.2019].

[17] Esteban González J. M., Muñoz Vicente A., Blanco Jiménez F. J., Breve historia y criterios de intervención en el teatro romano de Cádiz, "Teatros romanos de Hispania" 1992, pp. 141-156.

[18] Genoves Park's Lookout and Protection Building / José Luis Bezos Alonso, http://www.archdaily.com [accessed: 1.06.2019].

[19] Hammer P.E.J., Myth-Making: Politics, Propaganda and the Capture of Cadiz in 1596, 1997, https://cambridge.org/ core/journals/historical-journal/article/mythmaking-politics-propaganda-and-the-capture-of-cadiz-in-596 [accessed: 20.06.2019].

[20] Jones S., 'What the hell have they done?' Spanish castle restoration mocked, 09.03.2016, https://www.theguardian.com/ world/2016/mar/09/matrera-castle-cadiz-spain-restoration-mocked [accessed: 20.06.2019].

[21] Matrera Castle Intervention Heritage by Carlos Quevedo Rojas, https://competition.adesignaward.com/ [accessed: 19.06.2019]. 
[22] McManus D., Matrera Castle Restoration, Cádiz, 21.05.2019, https://www.e-architect.co.uk/spain/matrera-castle-restoration-cadiz [accessed: 19.06.2019].

[23] Megson K., Spanish architects win international prize for controversial restoration of medieval castle, 14.04.2016, http:// www.cladglobal.com/CLADnews/architecture-design/Architezter-A-awards-architecture-design-competition-restoration-Matrera-Castle-Spain-Carquero-Arquitectura/323328 [accessed: 21.06.2019].

[24] Mercado Central, http://www.destinationcadiz.com [accessed: 19.05.2019].

[25] Mercado Central de Cadiz, Rehabilitación y Ampliación / Carlos de Riaño Lozano, https://www.archdaily.com [accessed: 15.05.2019].

[26] Morgado García A., Horozco A., Historia de Cádiz, Cádiz 2001.

[27] Nash E., 'Europe's oldest city' is found, 2007, https://www.independent.co.uk/news/world/europe/europes-oldest-city-is-found-5328361.html [accessed: 4.07.2019].

[28] Pachon P., Rodriguez-Mayorga E., Jimenez J. F., Compan V., Saez A., Yanes E., Application of the operational modal analysis method for the control of the intervention in the Roman Theatre (Cádiz, Spain), [in:] Structures and Architecture: Concepts, Applications and Challenges, ed. P. J. Cruz, London 2013.

[29] Perondi V., El Teatro Romano que se resistió a morir, 22.07.2017, https://www.lavozdelsur.es/el-teatro-romano-que-se-resistio-a-morir/ [accessed: 15.06.2019].

[30] Project of the Week: Matrera Castle, Cadiz, Spain, Carquero Arquitectura, 31.03.2017, http://www.worldbuild365.com [accessed: 26.06.2019].

[31] Protection Building of the Genovés Park Cádiz (Spain), 2015, http://www.publicspace.org [accessed: 30.05.2019].

[32] Radziszewski H., Mityczne początki Kadyksu: wybór źródet, „Studia i Materiały Archeologiczne” vol. 12, 2005, pp. 163-168.

[33] Schmidt N., 'Between Cathedrals' by Estudio Arquitectura Campo Baeza, 2010, https://www.dailytonic.com/between-cathedrals-by-estudio-arquitectura-campo-baeza-es/ [accessed: 25.05.2019].

[34] Sobot R., Is this the world's worst restoration project? Historians furious after Ninth Century Spanish castle is 'repaired' by local builders, 09.03.2016, https://www.dailymail.co.uk/news/article-3484505/Historians-furious-Spanish-castle-repaired-builders.html [accessed: 25.06.2019].

[35] Teatro romano de Cádiz, http://www.juntadeandalucia.es/cultura/enclaves/enclave-arqueologico-teatro-romano-de-cadiz [accessed: 15.06.2019].

[36] Transcending Architecture. Contemporary Views on Sacred Space, ed. J. Bermudez, CUA Press 2015.

[37] Wainwright O., Some front: the bad developments making a joke of historical buildings, 25.08.2014, https://www.theguardian.com/artanddesign/architecture-design-blog/ [accessed: 20.06.2019].

[38] Wainwright O., Spain's concrete castle: a case of accidental genius?, 10.03.2016, https://www.theguardian.com/artanddesign/architecture-design-blog/ [accessed: 24.06.2019].

[39] Weiss A., Facadectomy is Preservationists' Biggest Mistake, 03.02.2004, https://www.planetizen.com/ [accessed: 27.06.2019].

[40] https://aprende.liceus.com/theatrum-balbi-teatro-romano-cadiz/ [accessed: 2.07.2019].

[41] https://www.britannica.com/place/Cadiz-Spain [accessed: 4.07.2019].

[42] http://cadizturismo.com/destinos/provincias/cadiz/municipios/cadiz/historia [accessed:1.07.2019].

[43] https://cometocadiz.com/theatrum-balbi-in-gades-roman-cadiz [accessed:1.07.2019].

[44] https://encyklopedia.pwn.pl/haslo/Kadyks;3918943.html [accessed: 4.07.2019].

[45] http://joseluisbezos.com/wordpress/urbanizacion-del-nuevo-paseo-de-santa-barbara/ [accessed: 3.07.2019]. 